\title{
GNRs@SiO $\mathbf{S}_{2}$-FA in combination with radiotherapy induces the apoptosis of HepG2 cells by modulating the expression of apoptosis-related proteins
}

\author{
BIN GAO $^{1}$, LEI SHEN ${ }^{1}$, KE-WU HE $^{1}$ and WEI-HUA XIAO ${ }^{2}$ \\ ${ }^{1}$ Department of Interventional Radiology, The Third Affiliated Hospital of Anhui Medical University, Hefei, Anhui 230061; \\ ${ }^{2}$ School of Life Science, University of Science and Technology of China, Hefei, Anhui 230022, P.R. China
}

Received March 30, 2015; Accepted September 11, 2015

DOI: $10.3892 / \mathrm{ijmm} .2015 .2358$

\begin{abstract}
The aim of the present study was to examine the apoptosis of the hepatocellular carcinoma cell line, HepG2, induced by treatment with folic acid-conjugated silica-coated gold nanorods (GNRs@SiO ${ }_{2}$-FA) in combination with radiotherapy, and to determine the involvement of apoptosis-related proteins. An MTT colorimetric assay was used to assess the biocompatibility of GNRs@ $\mathrm{SiO}_{2}$-FA. The distribution of GNRs@SiO ${ }_{2}$-FA into the cells was observed using transmission electron microscopy (TEM). HepG2 cells cultured in vitro were divided into the following 4 groups: i)the control group (untreated), ii) the GNRs@ $\mathrm{SiO}_{2}$-FA group, iii) the radiotherapy group (iodine 125 seeds) and iv) the combination group (treated with GNRs@ $\mathrm{SiO}_{2}$-FA and iodine 125 seeds) groups. The apoptosis of the HepG2 cells was detected by flow cytometry. The concentration range of $<40 \mu \mathrm{g} / \mathrm{ml}$ GNRs@ $\mathrm{SiO}_{2}-\mathrm{FA}$ was found to be safe for the biological activity of the HepG2 cells. GNRs@SiO ${ }_{2}$-FA entered the cytoplasm through endocytosis. The apoptotic rates of the HepG2 cells were higher in the GNRs@SiO ${ }_{2}$-FA and radiotherapy groups than in the control group $(\mathrm{P}<0.05)$. The apoptotic rate was also significantly higher in the combination group than the GNRs@ $@ \mathrm{SiO}_{2}-\mathrm{FA}$ and radiotherapy groups $(\mathrm{P}<0.05)$. Taken together, these findings demonstrate that the combination of GNRs@ $\mathrm{SiO}_{2}-\mathrm{FA}$ and radiotherapy more effectively induces the apoptosis of HepG2 cells. These apoptotic effects are achieved by increasing the protein expression of Bax and caspase- 3 , and inhibiting the protein expression of $\mathrm{Bcl}-2$ and $\mathrm{Ki}-67$. The combination of GNRs@ $\mathrm{SiO}_{2}$-FA and radiotherapy may thus prove to be a new approach in the treatment of primary liver cancer.
\end{abstract}

Correspondence to: Dr Bin Gao, Department of Interventional Radiology, The Third Affiliated Hospital of Anhui Medical University, 390 Huaihe Road, Luyang, Hefei, Anhui 230061, P.R. China

E-mail: gaobin_3136@163.com

Key words: Bax, Bcl-2, cell apoptosis, gold nanorods, hepatocarcinoma, iodine 125 seeds, hepatocarcinoma, Ki-67

\section{Introduction}

Hepatic cancer is a common malignant tumor, which ranks fifth in terms of global incidence and third in terms of cancer-related mortality worldwide (1). Although surgery is the preferred treatment option for patients with hepatic cancer, the overall morbidity rate following resection is only about $22-42 \%$ (2). Therefore, the treatment of hepatic cancer involves the joint application of various types of non-surgical treatments. The implantation of radioactive iodine 125 seeds has been used widely in the treatment of hepatic cancer, with profound effects. The process of particle implantation is performed manually, and is done irrespective of the 'hot' and 'cold' spots of radiation (3). Full conformal radiotherapy is difficult to implement.

As a novel precious material, metal nanoparticles, namely gold nanorods (GNRs) have unique optical properties (4), and have a low toxicity and good biocompatibility (5). GNRs have been used as a radiation sensitizer (6). Currently, GNRs are being used in combination with internal radiotherapy in targeted cancer therapy and are becoming a hotspot in cancer treatment $(7,8)$. However, GNRs require certain surface modifications to ensure good compatibility in order to provide the optimal effects from their clinical application. Silica-coated gold nanorods (GNRs@SiO 2 ) are relatively easy to prepare, and may help to maintain low levels of cytotoxicity. The silica surface is easy for amination, as its surface amino integrates with the carboxyl of folic acid (FA) to build a covalent bond, and this functions as a bridge for the folate-conjugated GNRs. Research has shown that FA receptors are highly expressed on the surface of malignant cancer cells than on normal cells (9). However, hepatic colorectal cancer cells have a surfaces rich in FA receptors (10); FA are natural ligands and a strong binding force for FA receptors. Therefore, FA may be used as a tumor targeting factor, and FA may be efficiently targeted into the liver cancer cells (11); thus, it may lay the foundation for folatetargeted cancer therapy.

In this study, we investigated a new treatment method. We used iodine 125 seeds to irradiate tumor cells, as well as folic acid-conjugated silica-coated GNRs (GNRs@SiO ${ }_{2}$-FA) to target folate receptors highly expressed on the surface membrane of cancer cells, as described in a previous study (4). The present study aimed to investigate the apoptosis of the 
hepatocellular carcinoma cell line, HepG2, induced by treatment with GNRs@ $\mathrm{SiO}_{2}$-FA in combination with radiotherapy. In addition, we examined the involvement of apoptosis-related proteins (e.g., Bax, Bcl-2, Ki67) in these effects.

\section{Materials and methods}

Materials. HepG2 cells were obtained from the cell bank of the Type Culture Collection of Chinese Academy of Sciences (Shanghai, China). Cell culture reagents were purchased from Gibco, Carlsbad, CA, USA. Chlorauric acid $\left(\mathrm{HAuCl}_{4} \cdot 3 \mathrm{H}_{2} \mathrm{O}\right)$, 1-ethyl-3-(3-dimethylaminopropyl)carbodiimide hydrochloride (EDC), N-hydroxysuccinimide (NHS), folic acid (FA) and (3-aminopropyl)triethoxysilane (APTS) were purchased from Sigma (St. Louis, MO, USA); cetyltrimethylammonium bromide $(\mathrm{CTAB})$, silver nitrate $\left(\mathrm{AgNO}_{3}\right)$ and sodium borohydride $\left(\mathrm{NaBH}_{4}\right)$ were from Aladdin (Shanghai, China); tetraethoxysilane (TEOS) and ascorbic acid were obtained from Sinopharm Chemical Reagent Co., Ltd. (Shanghai, China). 2,5-Diphenyltetrazolium bromide (MTT) and cell apoptosis reagents were purchased from BestBio (Shanghai, China). Polymerase chain reaction (PCR)-related reagents and cell incubators were purchased from Thermo Fisher Scientific, Inc. (Rockford, IL, USA). Anti-Bax (ab77566), anti-Bcl-2 (15071s) and anti-Ki-67 (PB0065) antibodies were purchased from Abcam (Cambridge, UK), Cell Signaling Technology (Danvers, MA, USA) and Boster Biological Technology, Ltd. (Wuhan, China), respectively.

Synthesis and characterization of GNRs@SiO $2-F A$. The gold nanorods (GNRs) were synthesized as previously described (12). Briefly, $0.6 \mathrm{ml}$ ice-cold $0.01 \mathrm{M} \mathrm{NaBH}_{4}$ was mixed with $10 \mathrm{ml}$ of aqueous solution containing $7.5 \mathrm{ml} 0.2 \mathrm{M} \mathrm{CTAB}$ and $2.5 \mathrm{ml}$ $0.001 \mathrm{M} \mathrm{HAuCl}_{4}$ under vigorous stirring. It was then kept at $25^{\circ} \mathrm{C}$ for at least $2 \mathrm{~h}$ prior to use as a seed solution. The growth solution contained $50 \mathrm{ml} 0.2 \mathrm{M} \mathrm{CTAB}, 50 \mathrm{ml} 0.001 \mathrm{M} \mathrm{HAuCl}_{4}$, $1 \mathrm{ml} 0.004 \mathrm{M} \mathrm{AgNO}_{3}$ and $0.7 \mathrm{ml} 0.0778 \mathrm{M}$ ascorbic acid. After gently mixing the growth solution, $80 \mu \mathrm{l}$ of seed solution were added and kept at $30^{\circ} \mathrm{C}$ for $24 \mathrm{~h}$ to obtain the GNRs.

Next, the spherical core-shell silica-coated GNRs (GNRs@ $\mathrm{SiO}_{2}$ ) were successfully prepared using the sol-gel method. First, the obtained GNRs were washed with deionized water twice to remove the excess CTAB and redispersed in $40 \mathrm{ml}$ of water. Subsequently, aqueous ammonia solution was added to obtain a $\mathrm{pH}$ of approximately 10 , and $8 \mathrm{ml}$ of $10 \mathrm{mM}$ TEOS/ethanol solution were added to the solution. The reaction mixture was allowed to react for $24 \mathrm{~h}$ under vigorous stirring. The resulting mesoporous silica-coated GNRs (GNRs@SiO ${ }_{2}$ )were redispersed in absolute ethyl alcohol. Finally, the GNRs@ $\mathrm{SiO}_{2}$ were conjugated with folic acid (GNRs@SiO $-\mathrm{FA})$. EDC and NHS were used to activate the carboxyl groups of folic acid (Fig. 1).

Cell culture. The human hepatocellular carcinoma cell line, HepG2, was used in the experiments. The cells were cultured in Dulbecco's modified Eagle's medium (DMEM) supplemented with $10 \%$ fetal bovine serum (FBS) (both from Gibco) at $37^{\circ} \mathrm{C}$ in a $5 \% \mathrm{CO}_{2}$ humidified incubator (Thermo Fisher Scientific, Inc.).

Cell viability assay. The HepG2 cells were cultured in a 96-well plate at a density of $5 \times 10^{3}$ cells $/ \mathrm{ml}$ for $24 \mathrm{~h}$, and the culture medium was then replaced with solutions containing either GNRs, GNRs@SiO , or GNRs@SiO $-\mathrm{FA}$, which were pre-mixed with fresh DMEM supplemented with $10 \%$ FBS [gold $(\mathrm{Au})$ concentrations were 40, 20, 10, 5 and $2.5 \mathrm{ppm}$ ]. Untreated cells served as the controls. The cells were cultured for a further $48 \mathrm{~h}$, and the culture medium was then replaced with $0.2 \mathrm{ml}$ fresh culture medium containing MTT assay reagent $(4 \mathrm{mg} / \mathrm{ml})$, followed by incubation for a further $4 \mathrm{~h}$. DMSO $(100 \mu \mathrm{l})$ was added to each well to dissolve the colored crystals. The optical density of the colored product was measured at $490 \mathrm{~nm}$ using a microplate reader (BioTek ELx800; Bio-Tek Instruments Inc., Winooski, VT, USA).

Transmission electron microscopy (TEM) to determine the distribution of GNRs@SiO$-F A$ within cells. The HepG2 cells were cultured in DMEM medium supplemented with 10\% FBS, under standard cell culture conditions $\left(5 \% \mathrm{CO}_{2}, 37^{\circ} \mathrm{C}\right)$ for $24 \mathrm{~h}$. The cells were washed 3 times with phosphate-buffered saline (PBS). The experimental group was treated with $9 \mathrm{ml}$ of DMEM medium and $1 \mathrm{ml}$ of $40 \mu \mathrm{g} / \mathrm{ml}$ GNRs@ $\mathrm{SiO}_{2}-\mathrm{FA}$ solution, and the control group (untreated) was treated with $10 \mathrm{ml}$ DMEM medium. The cells in the experimental group were then fixed with $2.5 \%$ glutaraldehyde, followed by ethanolacetone gradient dehydration and embedding in epoxy resin. The cells were then visualized under a transmission electron microscope (JEM-2100; JEOL, Tokyo, Japan).

Determination of targeting efficacy of GNRs@SiO $-F A$. The HepG2 cells were cultured in a 6-well plate at a density of $5 \times 10^{4}$ cells $/ \mathrm{ml}$ for $24 \mathrm{~h}$. The cells were divided into 2 groups: in one group, $100 \mu \mathrm{l}$ of GNRs@SiO $\mathrm{Si}_{2}$ were added to each well, and in the other group, $100 \mu \mathrm{l}$ of GNRs@ $\mathrm{SiO}_{2}-\mathrm{FA}$ were added to each well. The cells were then incubated in humidified air at $37^{\circ} \mathrm{C}$ with $5 \% \mathrm{CO}_{2}$. The cultivation of cells was terminated after 1, 4, 8, 16 and $24 \mathrm{~h}$, and this was followed by the collection of the cells, the detection of Au elements by inductively coupled plasma mass spectrometry (ICP-MS), and the calculation of the cell solid Au element content per kilogram.

First, a total of $10(2 \mathrm{ml})$ centrifuge tubes $(\mathrm{mg})$ were measured for electronic balance. Before the cells were harvested, they were washed with PBS 3 times to remove the free GNRs@ $\mathrm{SiO}_{2}-\mathrm{FA}$ and GNRs@SiO 2 . The cells were then digested with $300 \mu 10.25 \%$ trypsin. This was followed by the addition of $500 \mu \mathrm{l}$ DMEM and $1 \mathrm{ml}$ PBS, and the cells were then collected and placed within weighed $2 \mathrm{ml}$ centrifuge tubes. Next, using a thermostat (60 degrees), the centrifuge tubes containing the cells were dried. They were then weighed for electronic balance, and the quality of the cell solid material was obtained by subtracting the previous record of quality. This was followed by the additino of $500 \mu \mathrm{l}$ aqua regia to each tube, and the solid material was dissolved by ultrasound, with the addition of triple-distilled water to a final volume of $10 \mathrm{ml}$. Finally, the Au element was detected by ICP-MS and the Au element content was caclulated per $\mathrm{kg}$ cell solids $(\mathrm{mg} / \mathrm{kg})$.

Apoptosis assay. HepG2 cells, cultured in vitro, were divided into the following 4 groups: i) the control group (untreated), ii) the GNRs@ $\mathrm{SiO}_{2}-\mathrm{FA}$ group $(40 \mu \mathrm{g} / \mathrm{ml})$, iii) the iodine 125 seeds group ( 9 grains, $0.8 \mathrm{mCi}$ ), and iv) the combination group (with GNRs@SiO 2 -FA and iodine 125 seeds). The cells in the 
Table I. Primers used for RT-PCR.

\begin{tabular}{|c|c|c|c|}
\hline & Forward primer & Reverse primer & $\begin{array}{l}\text { Amplified fragment } \\
\text { length (bp) }\end{array}$ \\
\hline Bax & 5'-GCCCACCAGCTCTGAGCAGATCAT-3' & 5'-CGGCAATCATCCTCTGCAGC-3' & 209 \\
\hline Bcl-2 & 5'-GACTTCGCCGAGATGTCCAG-3' & 5'-CAGGTGCCGGTTCAGGTACT-3' & 225 \\
\hline GAPDH & 5'-AGAAGGCTGGGGCTCATTTG-3' & 5'-AGGGGCCATCCACAGTCTTC-3' & 258 \\
\hline
\end{tabular}

RT-PCR, reverse transcription-polymerase chain reaction; GAPDH, glyceraldehyde 3-phosphate dehydrogenase.

4 groups were collected and washed twice with cold PBS. The cells were centrifuged at 2,000 rpm for $5 \mathrm{~min}$ and were then resuspended in $100 \mu 1$ of Annexin $\mathrm{V}$ binding buffer at a density of $1 \times 10^{6}$ cells $/ \mathrm{ml}$. The cells were incubated with $5 \mu \mathrm{l}$ of Alexa Fluor 488 Annexin $\mathrm{V}$ conjugate and $5 \mu \mathrm{l}$ of propidium iodide (PI) (both from BestBio) for $15 \mathrm{~min}$ at room temperature in the dark; $400 \mu \mathrm{l}$ of $1 \mathrm{X}$ binding buffer was added to each sample tube, and the samples were immediately analyzed using a flow cytometer (BD Biosciences, Franklin Lakes, NJ, USA). Histograms and statistics were processed using FlowJo software version 7.6.1.

Semi-quantitative reverse transcription (RT)-PCR. Bax and Bcl-2 mRNA expression levels were measured by RT-PCR. The HepG2 cells $\left(1 \times 10^{6}\right)$, which were treated with GNRs in combination with iodine 125 seeds, were collected and counted. The analysis was performed using the two-step RT-PCR kit (Takara Co., Dalian, China). The purity of the total RNA was determined using a UV spectrophotometer (UV-2450; Shimadzu Corp., Kyoto, Japan) at OD260/OD280 (>1.8). The amplification method was as follows: Bax, 30 cycles; Bcl-2, 32 cycles; GAPDH, 32 cycles $\left(94^{\circ} \mathrm{C}, 30 \mathrm{sec} ; 56^{\circ} \mathrm{C}, 30 \mathrm{sec} ; 72^{\circ} \mathrm{C}\right.$, $1 \mathrm{~min}$ ). The amplified product was analyzed by gel electrophoresis on a $2 \%$ agarose gel and EB staining (ImageJ software). The primer sequences and PCR product sizes are listed in Table I.

Western blot analysis. For protein extraction, protein extraction solution with protease inhibitor (1\% Triton-X100, 0.1\% SDS, $150 \mathrm{mM} \mathrm{NaCl}, 50 \mathrm{mM}$ Tris-HCl pH 7.4, $1 \%$ deoxycholic acid, 2 mM EDTA pH 8.0) was used, and the protein was quantified using a BCA Protein assay kit (Thermo Fisher Scientific, Inc.) to plot a standard curve. The protein samples were boiled for 5 min, loaded and subjected to SDS-polyacrylamide gel electrophoresis (PAGE), and were subsequently transferred onto a PVDF membrane. The membrane was blocked with 5\% BSA for $1 \mathrm{~h}$ at room temperature and probed with rabbit antibodies against Bcl-2, Bax and caspase-3 (anti-caspase-3 antibody from Cell Signaling Technology) (all 1:1,000 dilution) overnight at $4^{\circ} \mathrm{C}$. The membrane was washed with Tris- $\mathrm{HCl}$ buffer containing Tween-20 (TBST $20 \mathrm{mM}$ Tris-HCl, pH 7.4, $150 \mathrm{mM}$ $\mathrm{NaCl}$ and $0.05 \%$ Tween-20) and incubated in horseradish peroxidase (HRP)-conjugated secondary goat anti-rabbit antibody (Cat. no. 49620; Cell Signaling Technology) (1:4,000 dilution) for $1 \mathrm{~h}$ at room temperature. The blots were developed by adding electrochemiluminescence (ECL) detection reagents.
Immunostaining for Bcl-2, Bax and Ki-67 cell markers. Both the treated and untreated HepG2 cells were fixed with $4 \%$ paraformaldehyde for $15 \mathrm{~min}$. The cells were permeabilized for $10 \mathrm{~min}$ at room temperature in $0.4 \%$ Triton $\mathrm{X}-100$ diluted in PBS. The fixed cells were incubated overnight at $4^{\circ} \mathrm{C}$ with each of the primary antibodies: anti-Bax (1:100), anti-Ki-67 (1:100) and anti-Bcl-2 (1:50). On the following day, after 3 washes with PBS, the secondary biotin-labeled antibody (SP9001; ZSGB-BIO, Beijing, China) was used at 1:200. For color development, streptavidin was labeled with HRP at 1:200, using the streptavidin-biotin-peroxidase complex (SABC) method.

Immunohistochemical staining. Bax-positive staining (tan) was observed in the cytoplasm, and Bcl-2-positive staining (tan) sd was observed in the cytoplasm and cell membrane. To quantify protein expression in the various samples, a scoring method was applied. A mean percentage of positive cancer cells was determined from at least 5 areas at $x 400$ magnification and assigned to 1 of the following 5 categories, as previously described (13): 0 point, $<5 \%$; 1 point, $5-25 \%$; 2 point, $26-50 \%$; 3 point, $51-75 \%$; and 4 point, $>75 \%$. Points for staining and percentages were multiplied for a 10-point scale as follows: 0 point, negative (-); 1-3 points, weakly positive (+); 4-6 points, positive $(++)$; and 7-9 points, strongly positive $(+++)$. For cells that showed heterogeneous staining, the predominant pattern was taken into account for scoring. The percentage of positive cancer cells and the staining intensity were multiplied to produce a weighted score for each case. Cases with a weighted surviving score $<1$ were considered to be negative.

Positive Ki-67 staining was indicated by the presence of fine tan particles in the nucleus. Each slice was observed at $>10$ typical views (at a high magnification, $x 400$ ), counting at least 200 cells. The percentage of positive cells indicated the $\mathrm{Ki}-67$ cell proliferation index, which was termed KI.

Statistical analysis. Statistical analysis was performed using SPSS 16.0 software for Windows. The cell survival rate was determined by MTT assay and the differences in the apoptotic rate in the 4 groups was analyzed by one-way ANOVA. P-values $<0.05$ were considered to indicate statistically significant differences.

\section{Results}

Synthesis of GNRs@SiO $-F A$ and cellular uptake. GNRs@ $\mathrm{SiO}_{2}$-FA distribution in the cells was determined by TEM. The prepared GNRs@SiO 2 -FA had an ellipsoid shape. 


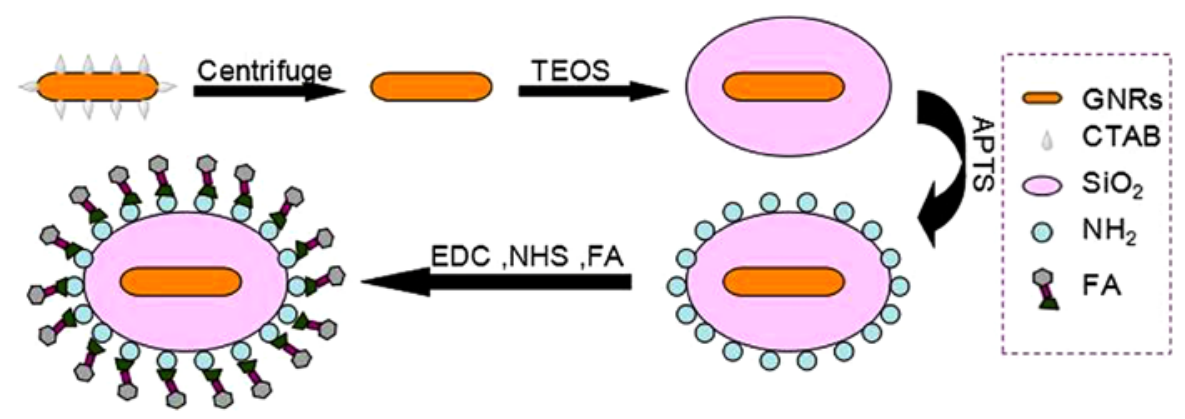

Figure 1. Synthetic procedure used to obtain GNRs@SiO 2 -FA. GNRs, gold nanorods; GNRs@SiO $-\mathrm{FA}$, folic acid-conjugated silica-coated gold nanorods.
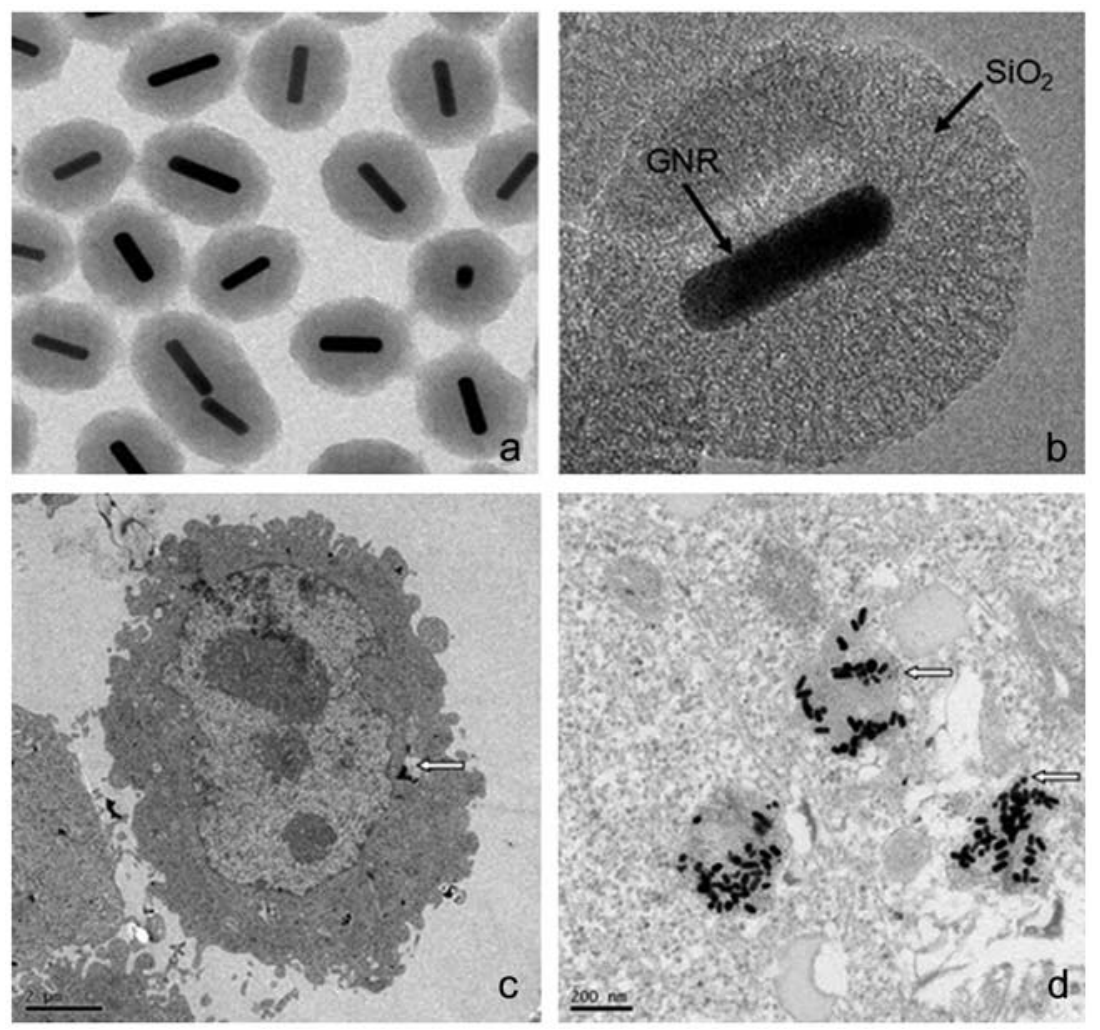

Figure 2. (a and b) Transmission electron microscopy (TEM) images of folic acid-conjugated silica-coated gold nanorods (GNRs@SiO 2 -FA). (c and d) TEM

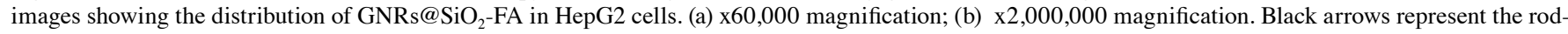
like structure of GNR and the mesoporous structure of $\mathrm{SiO}_{2}$ and white arrows indicate aggregated $\mathrm{GNRs}_{\mathrm{S}} @ \mathrm{SiO}_{2}-\mathrm{FA}$.

The GNRs were composed of a central rod, approximately $40 \mathrm{~nm}$ long and $10 \mathrm{~nm}$ wide, with a coating of silica on the surface. We demonstrated that GNRs@SiO - FA entered the cells in the form of nanoparticles. We also found that following entry into the cell, the ellipsoid shape of the GNRs@ $\mathrm{SiO}_{2}-\mathrm{FA}$ was retained (Fig. 2).

GNRs decrease cell viability at the concentration $>5 \mathrm{ppm}$. The results of MTT assay revealed that cell viability decreased as the GNR concentration increased in the culture medium. The cell survival rates in each group were as follows: GNRs group were 59.1, 71.8, 80.5, 85.3 and 91.1\%; the GNRs@ $\mathrm{SiO}_{2}$ group were 80.3, 85.7, 88.8, 95.8 and 97.1\% ; and the GNRs@ $\mathrm{SiO}_{2}-\mathrm{FA}$ group were $92.3,93.6,95.4,98.7$ and $99.4 \%$, respectively compared to treatment with $2.5,5,10,20$ and 40 ppm of the GNRs/ GNRs@SiO $2 /$ GNRs@SiO - FA. When the concentration of the Au element was $\geq 5$ ppm, all 3 groups (GNRs, GNRs@ $\mathrm{SiO}_{2}$ and
GNRs@SiO2-FA) exhibited statistically significant differences compared to the untreated controls $(\mathrm{P}<0.05)$. The cell growth inhibitory effects of GNRs@ $\mathrm{SiO}_{2}$-FA were not as prominent as those of the GNRs and GNRs@SiO 2 . The GNRs alone had the most prominent inhibitory effect on cell growth (Fig. 3).

Targetingefficacy of GNRs@SiO-FA. As shown in Fig. 4, the cellular uptake rate of GNRs@SiO $-\mathrm{FA}$ was 2.65-fold higher than that of GNRs@SiO ${ }_{2}$ at $4 \mathrm{~h}$, and the cellular uptake rate in both groups reached a plateau at subsequent time points (16 and $24 \mathrm{~h}$. This indicated that we had successfully prepared GNRs@SiO 2 -FA with a high targeting ability, and with the ability to bind with folate receptors within a short period of time. This experiment also revealed that nanoparticles can enter cells by endocytosis; however, entry by endocytosis is less efficient compared with the folate receptor-mediated entry of nanoparticles into cells. 


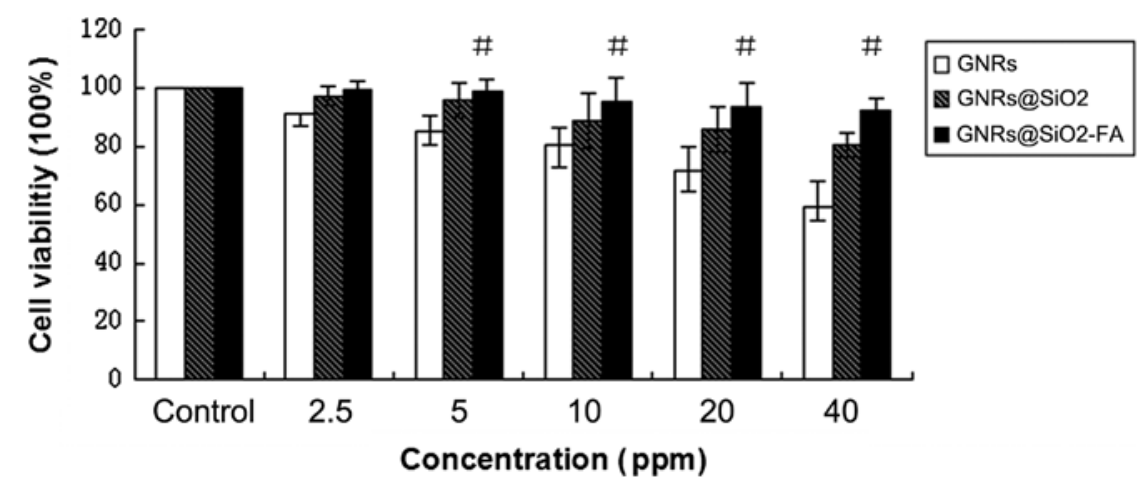

Figure 3. Viability of $\mathrm{HepG} 2$ cells treated with various concentrations of GNRs, GNRs@ $@ \mathrm{SiO}_{2}$ and $\mathrm{GNRs}_{\mathrm{S}} \mathrm{SiO}_{2}-\mathrm{FA}$ for $48 \mathrm{~h} .{ }^{*} \mathrm{P}<0.05$, compared to controls. GNRs, gold nanorods; GNRs@ $\mathrm{SiO}_{2}$, silica-coated gold nanorods; GNRs@ $\mathrm{SiO}_{2}$-FA, folic acid-conjugated silica-coated gold nanorods.

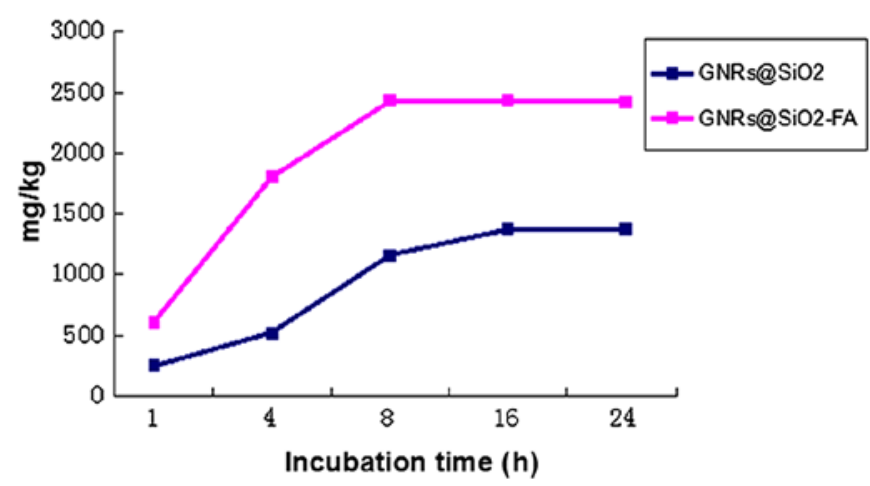

Figure 4. Uptake of GNRs@SiO 2 and GNRs@SiO $-\mathrm{FA}$ by HepG2 cells analyzed by inductively coupled plasma mass spectrometry (ICP-MS).GNRs@ $\mathrm{SiO}_{2}-\mathrm{FA}$, folic acid-conjugated silica-coated gold nanorods; GNRs@ $\mathrm{SiO}_{2}$, silica-coated gold nanorods.

GNRs@SiO- $-F A$ significantly increase the apoptosis of HepG2 cells. The apoptotic rates of the HepG2 cells were higher in the GNRs@SiO -FA group and the iodine 125 seeds group than in the control group $(\mathrm{P}<0.05)$. The apoptotic rate was also significantly higher in the combination group than in either the GNRs@ $\mathrm{SiO}_{2}$-FA group or iodine 125 seed group $(\mathrm{P}<0.05)$ (Fig. 5 and Table II).

GNRs@SiO-FA alters Bax and Bcl-2 mRNA expression in HepG2 cells. RT-PCR revealed that the mRNA expression of Bax significantly increased, and the mRNA expression of Bcl-2 significantly decreased in the combination group to a greater extent compared with either the GNRs@ $\mathrm{SiO}_{2}$-FA group or the iodine 125 seed group (Fig. 6).

GNRs@SiO $\mathrm{S}_{2}-\mathrm{FA}$ alters the protein expression of apoptosisrelated proteins. Western blot analysis revealed that the expression of the apoptosis-related proteins, Bax and caspase-3, was significantly upregulated in the combination group to a greater extent compared with either the GNRs@ $\mathrm{SiO}_{2}$-FA group or the iodine 125 seed group. The expression of Bcl-2 was, however, downregulated (Fig. 7).

GNRs@SiO $-F A$ alters the protein expression of apoptosisrelated proteins as shown by immunohistochemical staining
Table II. Apoptotic rate of HepG2 cells.

\begin{tabular}{lcc}
\hline Groups & $\mathrm{n}$ & Apoptotic rate (\%) \\
\hline Control group & 10 & $5.91 \pm 1.52$ \\
GNRs@ $\mathrm{SiO}_{2}$-FA group & 10 & $10.16 \pm 3.18$ \\
Iodine 125 seeds group & 10 & $20.78 \pm 4.79^{\mathrm{a}}$ \\
Combination group & 10 & $33.41 \pm 8.00^{\mathrm{a}}$ \\
F-value & & 99.82 \\
P-value & & 0.00 \\
\hline
\end{tabular}

aP $<0.05$ compared with other groups. GNRs@ $\mathrm{SiO}_{2}$, silica-coated gold nanorods; GNRs@ $\mathrm{SiO}_{2}$-FA, folic acid-conjugated silica-coated gold nanorods; $n$, number of experiments performed.

Bax protein expression in HepG2 cells. In the 4 groups of HepG 2 cells, the percentage of Bax-positive cells was found to be $0.95 \pm 0.18,1.51 \pm 0.44,4.29 \pm 0.86$ and $7.55 \pm 1.40$ in the control, GNRs@SiO ${ }_{2}$-FA, iodine 125 seed and the combination group, respectively. Compared with the GNRs@SiO $2-\mathrm{FA}$ and iodine 125 seeds groups, the protein expression level of Bax was significantly increased in the combination group $(\mathrm{P}<0.05)$ (Fig. 8 and Table III).

Bcl-2 protein expression in HepG2 cells. In the 4 groups of HepG2 cells, the percentage of Bcl-2-positive cells was $9.01 \pm 1.02,8.39 \pm 0.47,3.81 \pm 1.28$ and $1.70 \pm 0.83$ in the control, GNRs@ $\mathrm{SiO}_{2}$-FA, iodine 125 seed and the combination group, respectively. The protein expression level of Bcl-2 was much lower in the combination group than in the GNRs@SiO ${ }_{2}-\mathrm{FA}$ and iodine 125 seeds groups $(\mathrm{P}<0.05)$ (Fig. 8 and Table III).

Ki-67 protein expression in HepG2 cells. The cells in the control group were plump in shape. When the nuclei were hyperchromatic, the results were positive. The protein expression level of Ki-67 was significantly decreased in the combination group compared with the GNRs@ $\mathrm{SiO}_{2}$-FA and iodine 125 seeds groups $(\mathrm{P}<0.05)$, and the cell nuclei were stained lightly. In the 4 groups of cells, the Ki-67 proliferation index (KI) was $75.59 \pm 6.29,67.09 \pm 5.46,46.84 \pm 7.90$ and $27.90 \pm 5.83 \%$ in the control,GNRs@SiO $-\mathrm{FA}$, iodine 125 seed and the combination group, respectively, which was significantly different between the 4 groups $(\mathrm{P}<0.05)$ (Fig. 8). 

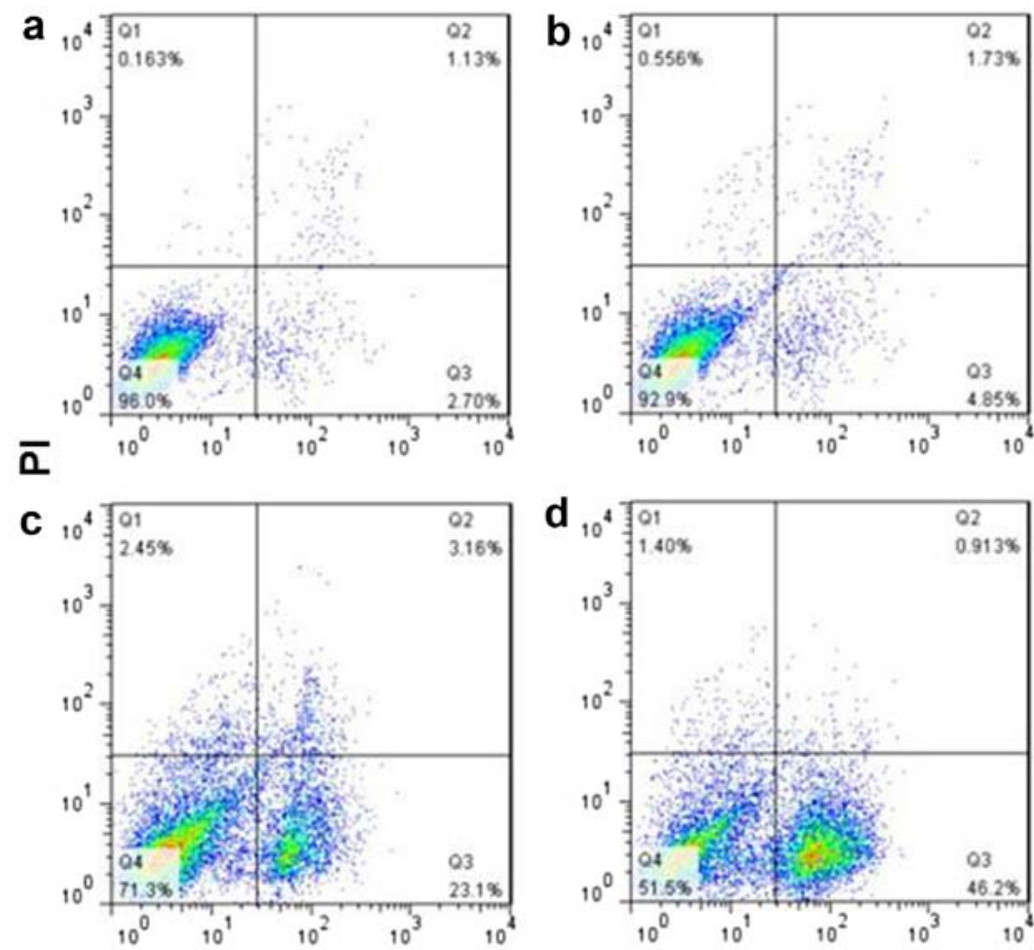

Annexin V

Figure 5. Effects of nanoparticle administration on the apoptosis in $\mathrm{HepG}^{2}$ cells determined by flow cytometry. (a) control group; (b) GNRs@SiO $\mathrm{GA}_{2} \mathrm{FA}$ group; (c) iodine 125 seeds group; (d) combination (GNRs@ $\mathrm{SiO}_{2}-\mathrm{FA}+$ iodine 125 seeds) group. GNRs@ $\mathrm{SiO}_{2}$, silica-coated gold nanorods; $\mathrm{GNRs} @ \mathrm{SiO}_{2}$-FA, folic acid-conjugated silica-coated gold nanorods.
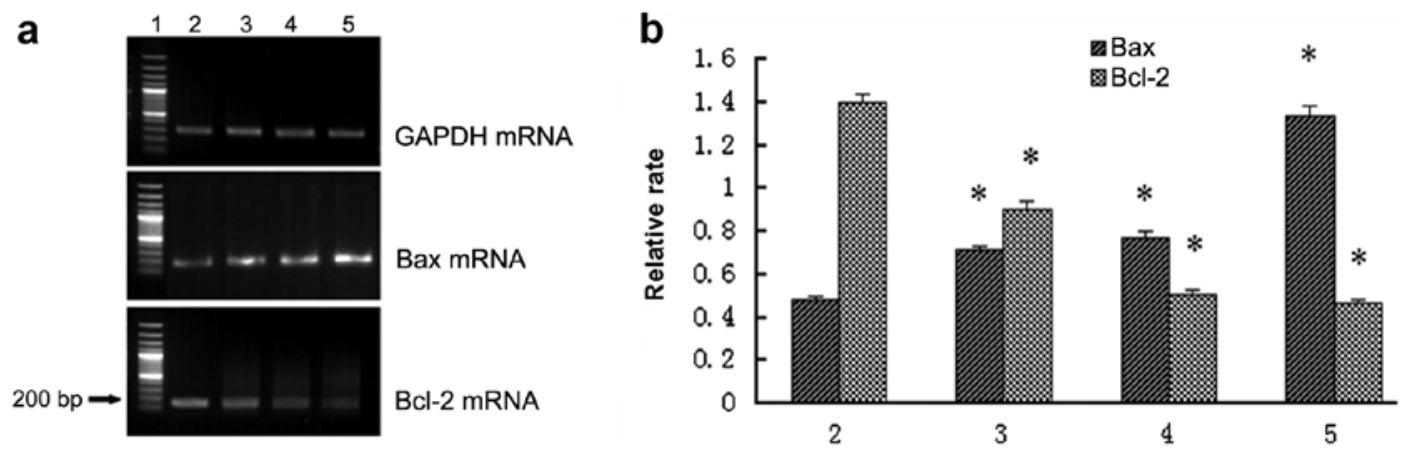

Figure 6. (a and b) RT-PCR results of Bax, Bcl-2 and GAPDH mRNA expression in HepG2 cells.Lane 1,DNA marker; lane 2, control group; lane 3, GNRs@SiO -FA group; lane 4, Iodine-125 seeds group; lane 5, combination (GNRs@ $\mathrm{SiO}_{2}-\mathrm{FA}+$ iodine 125 seeds) group; ${ }^{*} \mathrm{P}<0.05$, compared with control group. GNRs@SiO ${ }_{2}$, silica-coated gold nanorods; GNRs@ $\mathrm{SiO}_{2}$-FA, folic acid-conjugated silica-coated gold nanorods.
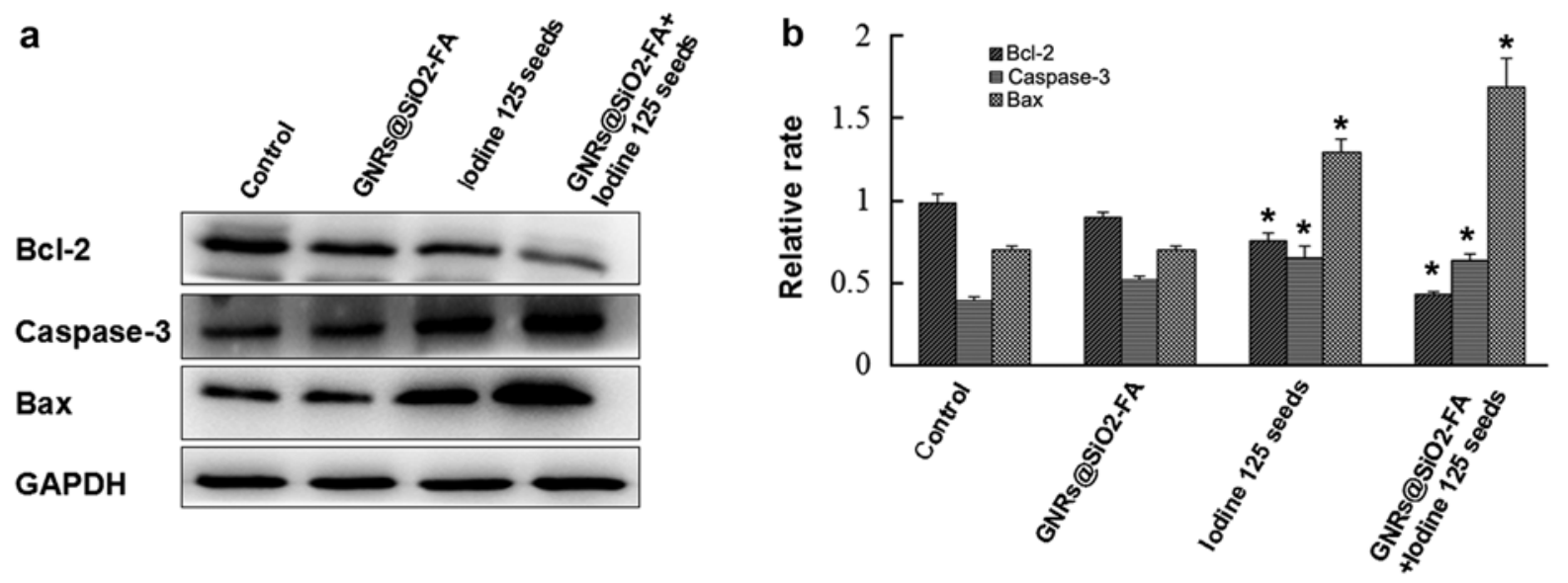

Figure 7. (a and b) Protein expression of Bcl-2, caspase-3 and Bax in HepG2 cells treated with GNRs@ $\mathrm{SiO}_{2}-\mathrm{FA}$, iodine 125 seeds, $\mathrm{GNRs}_{\mathrm{S}} \mathrm{SiO}$ - $\mathrm{FA}+$ iodine-125 seeds

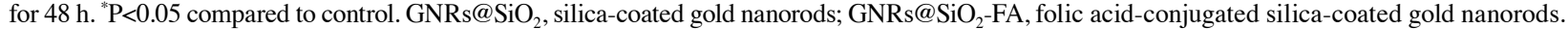




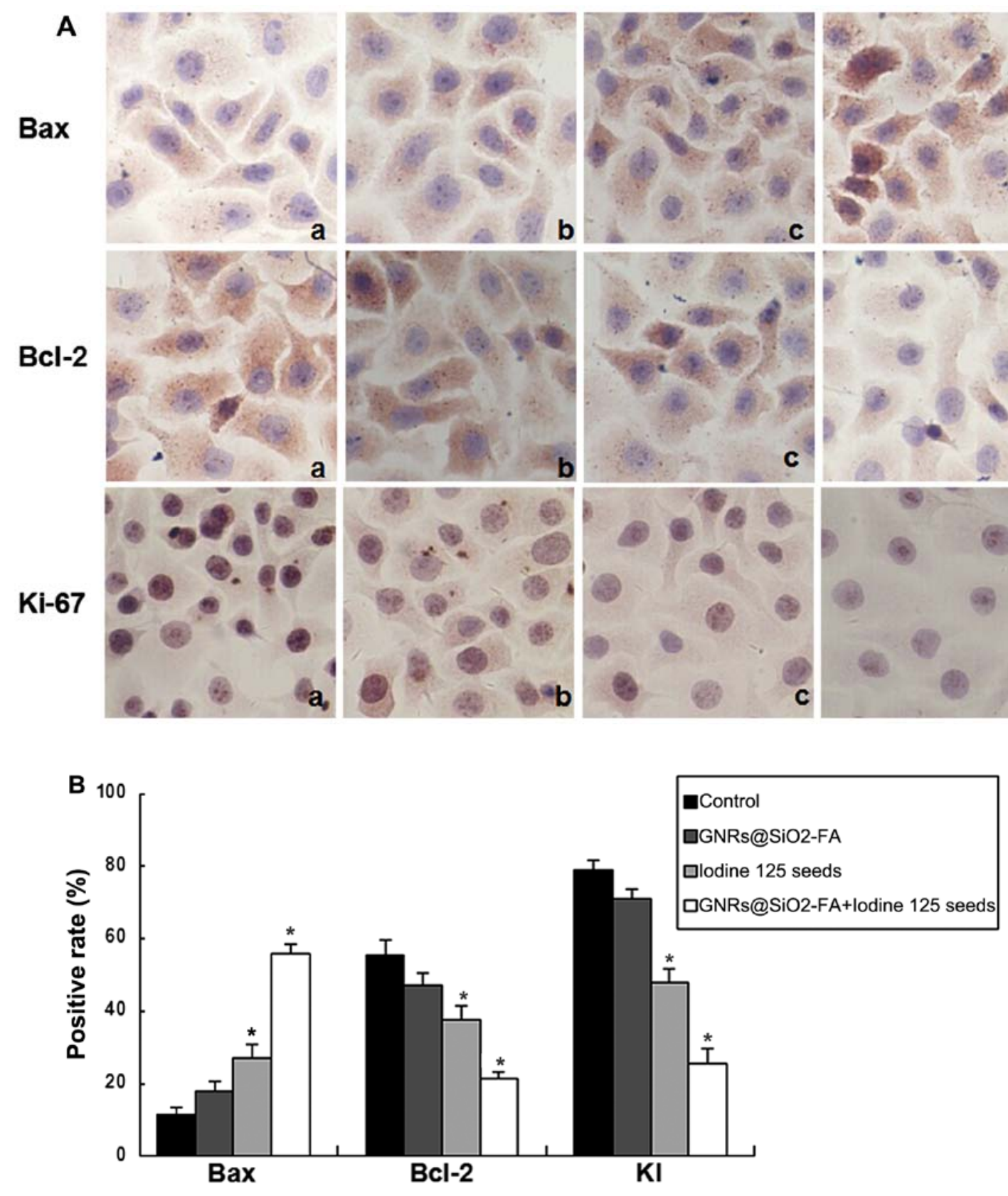

Figure 8. (A and B) Bax, Bcl-2 and Ki-67 protein expression in HepG2 cells in the different groups detected by immunohistochemistry. a) Control group; (b) GNRs@ $\mathrm{SiO}_{2}$-FA group; (c) iodine 125 seeds group; (d) GNRs@ $\mathrm{SiO}_{2}$-FA + iodine 125 seeds group. GNRs@SiO ${ }_{2}$, silica-coated gold nanorods; GNRs@ $\mathrm{SiO}_{2}$-FA, folic acid-conjugated silica-coated gold nanorods; KI, Ki-67 cell proliferation index. " $\mathrm{P}<0.05$ compared to control.

Table III. The integral value of Bax, Bcl-2, and KI in HepG2 cells in the different groups.

\begin{tabular}{lcccc}
\hline Groups & $\mathrm{n}$ & $\mathrm{Bax}$ & $\mathrm{Bcl}-2$ & $\mathrm{KI}$ \\
\hline Control group & 10 & $0.95 \pm 0.18$ & $9.01 \pm 1.02$ & $75.59 \pm 6.29$ \\
GNRs@ SiO 2 -FA group & 10 & $1.51 \pm 0.44$ & $8.39 \pm 0.47$ & $67.09 \pm 5.46$ \\
Iodine 125 seeds group & 10 & $4.29 \pm 0.86^{\mathrm{a}}$ & $3.81 \pm 1.28^{\mathrm{a}}$ & $46.84 \pm 7.90^{\mathrm{a}}$ \\
Combination group & 10 & $7.55 \pm 1.40^{\mathrm{a}}$ & $1.70 \pm 0.83^{\mathrm{a}}$ & $27.90 \pm 5.83^{\mathrm{a}}$ \\
F-value & & 74.49 & 84.60 & 109.98 \\
P-value & & 0.00 & 0.00 & 0.00 \\
\hline
\end{tabular}

Integral values are presented as a percentage $(\%)$. ${ }^{\mathrm{a}}<0.05$, compared with the control group and GNRs@ $\mathrm{SiO}_{2}$-FA group; n, number of experiments performed.

\section{Discussion}

In China, liver cancer is one of the malignant tumors with a high incidence, which has an insidious onset, rapid progression and alarmingly high mortality rates (14). The comprehensive treatment of hepatic cancer combining multiple methods, such as surgery, radiotherapy and chemotherapy may help in antagonizing the tumor (15). As normal hepatic tissues are poorly tolerant to radiation, it is not possible to increase the external irradiation dose used in the treatment of hepatic cancer; hence, the curative effect of external radiation therapy is poor. Compared with external radiation therapy, brachytherapy using iodine 125 seed implantation has the highest local dose and has a high dose close to the seed source and a steep fall in the dose 
for the surrounding tissues. After enough doses, it continues to kill the tumor cells; therefore, tumor tissue is damaged more thoroughly. However, the shortcoming of iodine 125 seed implant brachytherapy is that is is applied manually to existing cold and hot spots $(3,16)$ idicated by radiotherapy sensitization methods to achieve absolutely conformal radiotherapy.

This study investigated the GNRs@ $\mathrm{SiO}_{2}$-FA containing the element $\mathrm{Au}$, which has a high atomic number that enables it to infiltrate into cancer cells $(17,18)$. High atomic number materials, such GNRs enter cancer cells, producing stronger photoelectric absorption effects on cancer cells than on the surrounding normal cells. GNRs@ $\mathrm{SiO}_{2}-\mathrm{FA}$, in combination with radiotherapy, acts as a radiosensitization agent, thereby enhancing the efficacy of radiotherapy. This type of combination therapy has a more prominent photoelectric absorption effect, accelerating the DNA chain rupture, and eventually leading to cell death $(19,20)$.

Cell apoptosis is known as programmed cell death (PCD), and multiple genes are involved in this process. A previous study demonstrated that the delivery of programmed cell death protein $4(\mathrm{Pdcd} 4)$ in mice with liver cancer significantly suppressed tumor growth, induced apoptosis suppressed proliferation and angiogenesis (21). The coordinated action of apoptosis and anti-poptotic genes determines the initiation or inhibition of apoptosis (22). In this study, we selected Bcl-2, Bax, caspase-3 and Ki-67 as a testing index, observing the effects of GNRs@SiO $-\mathrm{FA}$ in combination with radiotherapy on their expression. Mitochondria are central to apoptotic processes and can even decide cell fate. The mitochondrial membrane regulates the apoptosis of $\mathrm{Bcl}-2$ family proteins, and the combination of the protein state will adjust the mitochondrial membrane potential, alter the expression of Cyt C (23) and Smac/DIABLO (24) proteins, as well as the release of AIF, activating the caspase pathway and lead to cell apoptosis; the mitochondria exerts this effect on promoting apoptosis through $\mathrm{Bax} / \mathrm{Bcl}-2$ and the regulation of caspases (25). Bcl-2 (26) is a type of mitochondrial transmembrane protein that can promote cell survival and inhibit apoptosis; it can prevent mitochondrial apoptosis before Cyt $\mathrm{C}$ blocks apoptosis, and members of the Bcl-2 family can be inserted in the mitochondrial outer membrane formation channels, thereby activating apoptosis. $\mathrm{Ki}-67$ (27) is a type of cell cycle-related proliferating nuclear antigen that is used as an independent prognostic indicator for curing hepatic cancer and achieving total survival. A decrease in Ki-67 expression (28) has been shown to suppress cancer cell proliferation. Electron microscopy revealed that the GNRs were mostly in the cytoplasm (Fig. 2c) after entering the cells and are likely to be located in the mitochondria (Fig. 2d). The mitochondria may absorb GNRs and accept iodine 125 particle irradiation simultaneously, and mitochondrial damage leads to apoptosis.

To the best of our knowledge, there have been limited studies published to date on the administration of GNRs in combination with iodine 125 particles. Our in vitro experiments confirmed that GNRs in combination with iodine 125 particles exerted marked synergistic anticancer effects. This study provides the experimental basis for hepatic cancer therapy using GNRs in combination with iodine 125 particles at the molecular level. However, a more detailed investigation is warranted in order to elucidate the specific biological mechanisms involved.

\section{Acknowledgements}

Dr B. Gao acknowledges the University of Science and Technology of China and the National Science Foundation grant no. 81071240 for their financial assistance.

\section{References}

1. Parkin DM, Bray F, Ferlay J and Pisani P: Global cancer statistics, 2002. CA Cancer J Clin 55: 74-108, 2005.

2. Ciacio O, Voron T, Pittau G, Lewin M, Vibert E, Adam R, Sa Cunha A, Cherqui D, Schielke A, Soubrane O, et al: Interest of preoperative immunonutrition in liver resection for cancer: study protocol of the PROPILS trial, a multicenter randomized controlled phase IV trial. BMC Cancer 14: 980, 2014.

3. Herron B, Herron A, Howell K, Chin D and Roads L: A Review of radiation therapy's role in early-stage breast cancer and an introduction to electronic brachytherapy. In: Cancer Treatment - Conventional and Innovative Approaches. Rangel L (ed). InTech, pp223-238, 2013. doi: 10.5772/55621.

4. Liu W, Zhu Z, Deng K, Li Z, Zhou Y, Qiu H, Gao Y, Che S and Tang Z: Gold nanorod@chiral mesoporous silica core-shell nanoparticles with unique optical properties. J Am Chem Soc 135: 9659-9664,2013.

5. Hu XG and Gao XH: Multilayer coating of gold nanorods for combined stability and biocompatibility. Phys Chem Chem Phys 13: 10028-10035, 2011.

6. Gui C and Cui DX: Functionalized gold nanorods for tumor imaging and targeted therapy. Cancer Biol Med 9: 221-233, 2012.

7. Xu W, Luo T, Li P, Zhou C, Cui D, Pang B, Ren Q and Fu S: RGD-conjugated gold nanorods induce radiosensitization in melanoma cancer cells by downregulating alpha(v)beta(3) expression. Int J Nanomedicine 7: 915-924, 2012.

8. Mackey MA, Ali MR, Austin LA, Near RD and El-Sayed MA: The most effective gold nanorod size for plasmonic photothermal therapy: theory and in vitro experiments. J Phys Chem B 118: 1319-1326, 2014.

9. Franzen SA: A comparison of peptide and folate receptor targeting of cancer cells: from single agent to nanoparticle. Expert Opin Drug Deliv 8: 281-298, 2011.

10. D'Angelica M, Ammori J, Gonen M, Klimstra DS, Low PS, Murphy L, Weiser MR, Paty PB, Fong Y, Dematteo RP, et al: Folate receptor-alpha expression in resectable hepatic colorectal cancer metastases: patterns and significance. Mod Pathol 24: 1221-1228, 2011.

11. Leamon CP: Folate-targeted drug strategies for the treatment of cancer. Curr Opin Investig Drugs 9: 1277-1286, 2008.

12. Pastoriza-Santos I, Perez-Juste J and Liz-Marzan LM: Silica-coating and hydrophobation of CTAB-stabilized gold nanorods. Chem Mater 8: 2465-2467, 2006.

13. Lo Muzio L, Staibano S, Pannone G, Mignogna MD, Mariggiò A, Salvatore G, Chieffi P, Tramontano D, De Rosa G and Altieri DC: Expression of the apoptosis inhibitor survivin in aggressive squamous cell carcinoma. Exp Mol Pathol 70: 249-254, 2001.

14. Ribas J, Bettayeb K, Ferandin Y, Knockaert M, Garrofé-Ochoa X, Totzke F, Schächtele C, Mester J, Polychronopoulos P, Magiatis P, et al: 7-Bromoindirubin-3'-oxim induces caspase-independent cell death. Oncogene 25: 6304-6318, 2006.

15. Liang P, Dong B, Yu X, Yu D, Cheng Z, Su L, Peng J, Nan Q and Wang H: Computer-aided dynamic simulation of microwaveinduced thermal distribution in coagulation of liver cancer. IEEE Trans Biomed Eng 48: 821-829, 2001.

16. Skowronek J: Low-dose-rate or high-dose-rate brachytherapy in treatment of prostate cancer - between options. J Contemp Brachytherapy 5: 33-41, 2013.

17. Roeske JC,Nunez L,Hoggarth M,Labay Eand Weichselbaum RR: Characterization of the theorectical radiation dose enhancement from nanoparticles. Technol Cancer Res Treat 6: 395-401, 2007.

18. Cho SH, Jones BL and Krishnan S: The dosimetric feasibility of gold nanoparticle-aided radiation therapy (GNRT) via brachytherapy using low-energy gamma-/x-ray sources. Phys Med Biol 54: 4889-4905, 2009.

19. Conde J, Doria G and Baptista P: Noble metal nanoparticles applications in cancer. J Drug Deliv 2012: 751075, 2012.

20. Jones B, Krishnan S and Cho SH: Estimation of microscopic dose enhancement factor around gold nanoparticles by Monte Carlo calculations. Med Phys 37: 3809-3816, 2010 
21. Kim JH, Minai-Tehrani A, Kim YK, Shin JY, Hong SH, Kim HJ, Lee HD, Chang SH, Yu KN, Bang YB, et al: Suppression of tumor growth in $\mathrm{H}$-ras $12 \mathrm{~V}$ liver cancer mice by delivery of programmed cell death protein 4 using galactosylated poly(ethylene glycol)chitosan-graft-spermine. Biomaterials 33: 1894-1902, 2012.

22. Green DR and Kroemer G: The pathophysiology of mitochondrial cell death. Science 305: 626-629, 2004.

23. Goodsell DS: The molecular perspective: $\mathrm{Bcl}-2$ and apoptosis. Stem Cells 20: 355-361, 2002.

24. Adrain C, Creagh EM and Martin SJ: Apotosis-associated release of Smac/DIABLO from mitochondrial requires active caspases and is blocked by Bcl-2. EMBO J 20: 6627-6663, 2001.

25. Liang H, Zhan HJ, Wang BG, Pan Y and Hao XS: Change in expression of apoptosis genes after hyperthermia, chemotherapy and radiotherapy in human colon cancer transplanted into nude mice. World J Gastroenterol 13: 4365-4371, 2007.
26. Jeong SY and Seol DW: The role of mitochondria in apoptosis. BMB Rep 41: 11-22, 2008.

27. Stroescu C, Dragnea A, Ivanov B, Pechianu C, Herlea V, Sgarbura O, Popescu A and Popescu I: Expression of p53, Bcl-2, VEGF, Ki67 and PCNA and prognostic significance in hepatocellular carcinoma. J Gastrointestin Liver Dis 17: 411-417, 2008.

28. Pichu S, Krishnamoorthy S, Shishkov A, Zhang B, McCue P and Ponnappa BC: Knockdown of Ki-67 by dicer-substrate small interfering RNA sensitizes bladder cancer cells to curcumininduced tumor Inhibition. PLoS One 7: e48567, 2012. 